\title{
THE MISSIONARY CHARACTER OF PAUL'S STAY ON MALTA (ACTS 28:1-10) ACCORDING TO THE EARLY CHURCH
}

\author{
RONALD H. VAN DER BERGH \\ UNIVERSITY OF PRETORIA
}

\begin{abstract}
Paul's apparent lack of preaching to the inhabitants of $\mathrm{M}$ alta in $\mathrm{A}$ cts 28:1-10 and his seeming indifference to being called 'a god' form a stark contrast to his usual missionary pattern in the narrative of A cts, possibly showing a lack of evangelistic concern among the 'barbarian' population of the island. This article investigates the reception of $A$ cts $28: 1-10$ in the writings of the $G$ reek- and $L$ atin speaking church (up to the end of the fifth century) to determine whether Paul's behaviour in Acts 28:1-10 was considered to be missionary in character. This proves to be the case, al though the missionary nature of his actions is substantiated in a variety of ways.
\end{abstract}

Keywords: M ission; barbarians; early Christian exegesis; Paul; M alta.

\section{INTRODUCTION ${ }^{1}$}

In the narration of Paul's stay on the island of $M$ alta ${ }^{2}$ in $A$ cts $28: 1-10$, his apparent

1 I would like to express gratitude to two anonymous peer reviewers who thoroughly read through this article and made helpful suggestions with regard to typographical errors in the manuscript, secondary literature and terminology.

2 The question of the true location of the island Medín (Acts 28:1) will not be discussed in this article. As the scholarly consensus takes $\mathrm{M}$ alta to be the intended island, this designation will be used. For a recent discussion of the issues involved, see Jens Börstinghaus, Sturmfahrt und Schiffbruch: Zur lukanischen Verwendung eines literarischen Topos in Apostelgeschichte 27,1-28,6 (ed. J. Frey; Tübingen: M ohr, 2010), 432-44. 
failure to preach to this island's inhabitants ${ }^{3}$ and his seeming indifference to being called 'a god' (Acts 28:6) ${ }^{4}$ form a stark contrast to his usual missionary ${ }^{5}$ pattern in the narrative of $A$ cts, ${ }^{6}$ a book in which the universalistic approach to the nations is

3 Cf. Richard I. Pervo, Acts: A Commentary (Hermeneia; Minneapolis: Fortress, 2008), 672; David Peterson, The Acts of the Apostles (The Pillar New Testament Commentary; Grand Rapids: Eerdmans, 2009), 701. A lso see Eckhard J. Schnabel, Paul and the Early Church (vol. 2 of Early Christian M ission; Downers Grove; InterVarsity, 2004), 1267, who notes that the author of Acts 'did not mention any missionary activity of Paul', but thinks it likely 'that Paul prayed for the sick in the name of J esus Christ'.

4 Compare, e.g., Paul and Barnabas' prompt protest at a similar situation of being ascribed divinity at Lystra, where they tear their clothes and chide the Lycaonians (A cts 14:8-18). The similiarities between Acts 14:8-18 and Acts 28:1-6 have been noted as early as Chrysostom, albeit with little comment - see the discussion below. A lthough some see this problem resolved in A cts 28:7-10 (e.g. M ikael C. Parsons, Acts [Paideia; Grand Rapids: B aker A cademic, 2008], 361; Charles H. Talbert, Reading Acts: A Literary and Theological Commentary on the Acts of the Apostles [M acon: Smyth \& Helwys, 2005], 218. Cf. B everly R. Gaventa, The Acts of the Apostles [A NTC; Nashville: A bingdon, 2003], 358), the text is not explicit in identifying the 'barbarians' of Acts 28:1-6 with the island's inhabitants in Acts 28:7-10.

5 It may be helpful to clear up the way in which the term 'mission' is employed in this article. Eckhard J. Schnabel, J esus and the Twelve (vol. 1 of Early Christian M ission; D owners Grove; InterVarsity, 2004), 10-11 proffers two main lines along which the term can be understood, namely 'a missionary dimension that is not directly missionary activity but implies universal or universalistic aspects' or 'missionary intention that is linked with specific actions and proceeds from a "center" from which envoys or "missionaries" are "sent"... to other people'. Schnabel's own definition of the term 'involves a threefold reality': '(1) people communicate to people of different faiths a new interpretation of reality - a different, new view of God, humankind and salvation; (2) people communicate a new way of life that replaces, at least partially, the former way of life; (3) people integrate those whom they win over to their faith and way of life into their community.' The present article understands mission along the lines of this 'threefold reality' that is to say, an activity aimed at communicating the perceived truth of the Christian faith with the goal of effecting a different view of reality and a change in lifestyle. The term 'mission' will be used interchangeably with similar terms, e.g. 'evangelistic concern'. Furthermore, it should be noted that the primary scope of this article is the interpretation of the text of A cts by the early church, and not the 'historical' Paul or the intended or implied first readers of Acts.

6 Cf. Pervo, Acts, 672. For a study on Paul's missionary pattern in Acts, cf. Robert C. Tannehill, 'R ejection by J ews and Turning to the Gentiles: The Pattern of Paul's M ission in Acts,' in Society of Biblical Literature 1986 Seminar Papers (ed. K. H. Richards; SBLSP; A tlanta: Scholars Press, 1986), 130-41. For a more general study of the 'historical' Paul's missionary tactics that integrates evidence from various sources, see Schnabel, Paul and the Early Church, 1293-1475, and Eckhard J. Schnabel, Paul the Missionary: Realities, Strategies and Methods (Downers Grove; InterVarsity, 2008), 256-356. 
The Missionary Character of Paul's Stay on Malta (Acts 28:1-10) according to the Early Church

apparent throughout. ${ }^{7}$ Paul's inconsistent behaviour in the Acts 28 narrative betrays a possible lack of evangelistic concern for 'the barbarian' (oi $\beta \alpha$ ó $\rho \beta \alpha \rho \imath)^{8}$ population of the island in Acts 28:1-6 by the author of Acts. ${ }^{9}$ The term 'barbarian' - the definitive marker of 'otherness' in the Greco-R oman world ${ }^{10}$ - is itself problematic here, occuring only two times, and only in this passage, in Acts (Acts 28:2,4) - a narrative filled with various language- and ethnic groups. ${ }^{11} \mathrm{Did}$ this description also cover the island's

7 Ben Witherington, The Acts of the Apostles: A Socio-Rhetorical Commentary (Grand Rapids: Eerdmans, 1998), 511-12. For an in-depth investigation into how the author of A cts understood the Gentiles and why the author thought it was necessary to evangelise them, see Christoph W. Stenschke, Luke's Portrait of Gentiles Prior to Their Coming to F aith (WUNT 108; Tübingen: M ohr, 1999).

8 The multivalent terms $\beta \alpha ́ \rho \beta \alpha \rho o s$ and barbarus will be translated in brackets in this article to avoid assigning it a pejorative meaning. A Iso see the discussion bel ow for further remarks on the terms' use in Acts.

9 A case can be made for the exact opposite. See, for instance, footnote 610 in Stenschke, Luke's Portrait of $\mathrm{G}$ entiles, 235.

10 There are numerous studies dealing with the word, its development and its use as a marker of 'otherness' in the Greco-Roman world, amongst which the following should be considered some of the foremost: A lbrecht Dihle, Die Griechen und die F remden (M unich: Beck, 1994); Bernd Funck, 'Studie zu der Bezeichnung $\beta \alpha ́ \rho \beta \alpha \rho \rho \varsigma$,' in U nter suchungen ausgewählter altgriechischer sozialer Typenbegriffe und ihr F ortleben in Antike und M ittelalter (ed. E. C. Welskopf; 4th ed.; B erlin: A kademie, 1981); Edith Hall, Inventing the Barbarian: Greek Self-Definition through Tragedy (Oxford: Clarendon, 1989); Hans Windisch, ‘ßóp $\beta \alpha \rho \rho \varsigma$, , TDNT 546-553. Even those with a more favourable view of different people groups' appraisal of one another in the ancient world have to concede its use as a marker of 'otherness': e.g. Erich S. Gruen, Rethinking the 0 ther in Antiquity (Princeton: Princeton University Press, 2011), 76. The term has found some acceptance among the early Christian apologists - cf. Stamenka E. A ntonova, 'B arbarians and the Empire-Wide Spread of Christianity,' in The Spread of C hristianity in the First F our Centuries: Essays in Explanation (ed. W. V. Harris; 27th ed.; Leiden: Brill, 2005), 69, but this acceptance was not to last; cf. Guy G. Stroumsa, Barbarian Philosophy: The Religious Revolution of Early Christianity (WUNT 112; Tübingen: Mohr, 1999), 65.

11 Whether the author used the term out of custom or out of protest is left undecided in the dictionary entry by Windisch, ' $\beta \alpha \alpha \rho \beta \alpha \rho \rho^{\prime}$,' 551. Commentaries on Acts also diverge in their opinion. For some, the term is only a linguistic or ethnic marker (e.g. Gaventa, Acts of the A postles, 357; J acob Jervell, Die Apostelgeschichte (KEKNT 3; Göttingen: Vandenhoeck \& Ruprecht, 1998), 615; Luke T. J ohnson, The Acts of the Apostles (ed. Daniel J. Harrington; 5th ed. Collegeville: The Liturgical Press, 1992), 461; I. Howard Marshall, The Acts of the Apostles: An Introduction and Commentary (Leicester: InterVarsity, 1980), 415-16; Jaroslav Pelikan, Acts (SCM Theological Commentary on the Bible; London: SCM, 2006), 290; Gerhard Schneider, Die Apostelgeschichte: II. Teil: Kommentar zu Kap. 9,1-28,31 (Freiburg: Herder, 1982), 401, while others assume a more pejorative use of the word, even if this is in protest (e.g. Pervo, Acts, 671; Peterson, Acts, 699; J ürgen R oloff, Die A postelgeschichte (Göttingen: Vandenhoeck \& Ruprecht, 1981), 366; John Van Eck, H andelingen: De Wereld in het Geding (K ampen: Kok, 2003), 548- 49. 
inhabitants that were healed in the separate episode in Acts 28:7-10? In other words, did the 'barbarians' benefit from Paul's healing actions on the island (which could be equated with some form of evangelisation) $)^{12}$ or did the author of Acts envision two groups of people on M alta?

The present article seeks to understand the response of the early church to these difficult textual questions. Did the writers and preachers ${ }^{13}$ of the early Greek- and Latin speaking church (up to the fifth century C.E.) pick up on the author of Acts' potentially elitist tendencies and if so, how did they respond? The article will examine the reception of Acts 28:1-10 with a view to four aspects: First, did early Christian writers consider A cts 28:1-10 to describe missionary activity by Paul, and if so, in what way did they consider it to be missionary? Second, how did early Christian writers perceive the use of the word 'barbarian' in A cts $28: 2,4$, and what was their own reaction to this term in its context? Third, how is the statement by the 'barbarians' that Paul is a god (Acts 28:6) evaluated by these writers? Finally, do the 'barbarians' in Acts 28:1-6 and the island's inhabitants in Acts 28:7-10 constitute the same people group? In what follows, each writer commenting on the A cts 28:1-10 episode will be scrutinised with regard to these four aspects. Of course, it will not be possible to answer all of these questions for every writer, and only those writers which contribute to at least one of these aspects will be considered. ${ }^{14}$ The discussion will proceed along an approximate chronological line.

\section{THE MISSIONARY CHARACTER OF ACTS 28:1-10 ACCORDING TO THE EARLY CHURCH}

\subsection{Tertullian}

The earliest extant reference by the early church to the episode related in Acts 28:1-10 can be found in the introduction of Tertullian's Scorpiace. ${ }^{15}$ He has just commented on the protective power of faith (fides) against the pestilent scorpion, after which he continues:

12 Cf. Jervell, Apostelgeschichte, 617; Gerhard A. Krodel, Acts (Minneapolis: Augsburg, 1986), 480.

13 In the rest of this article, the reference to 'writers' will be inclusive of those who were considered preachers. This is not to deny the oral setting of many of these works, but simply an acknowledgement that the extant material is only accessible through written texts.

14 References to Acts $28: 1-10$ by the early Christian writers that are not helpful in answering these questions will be pointed out in the footnotes of this article, even though they will not be discussed in detail.

15 Tertullian, 'Scorpiace,' in Q uinti Septimi F Iorentis Tertulliani opera: Pars II: O pera M ontanistica (ed. A. Reifferscheid and G. Wissowa; CCSL 2; Turnholt: Brepols, 1954), 1069. 
... in this way we often assist the pagans (ethnicis), as we have been gifted by God with that power which the apostle affirmed, when he spurned the bite of the viper. ${ }^{16}$

For Tertullian, faith enables assistance in this argument, but the nature of the assistance is unclear. It could be that Paul 'assisted' the pagans by converting them to the faith i.e., a case of seeing leads to believing; or it could be that Paul's preservation resulted in him 'assisting' the island's inhabitants by healing them, as is related in Acts 28:9. The implication is either that the 'barbarians' were converted, that both Acts 28:2-6 and A cts 28:7-10 refer to the same group of people, or that the 'barbarians' were converted and Acts 28:2-6 and Acts 28:7-10 refer to the same group. Tertullian's preference for the term ethnicus rather than barbarus is not due to his dislike for the latter term, ${ }^{17}$ but because the Acts 28:3-6 episode is used as a general assertion about all 'pagans', not just 'barbarians'.

\subsection{Eusebius of Caeserea}

In paragraph 63 of his Commentarius in Isaiam, Eusebius of Caesarea provides one of the foremost examples of the early church explicitly linking the episode in A cts 28:1-10 with evangelisation. ${ }^{18}$ Eusebius alludes to Acts $28: 1-10$ in his commentary on Isaiah 11:10-16, which concerns the 'conversion of the nations and the ingathering of the dispersion, the kind of text Eusebius likes to apply to the Christian evangelization of the Gentiles'. ${ }^{19}$ Eusebius emphasises the importance of the phrase 'and they will fly in foreigners' ships,

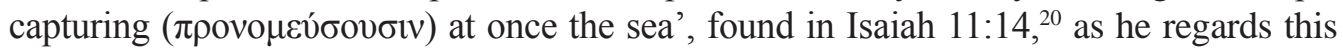
phrase as referring to the dissemination of the gospel. A ccording to him, the ships are necessary 'in order to proclaim the gospel to many nations in a short time' ${ }^{21} \mathrm{He}$ notes that the disciples, in traversing the sea, also proclaimed the gospel to those on the islands, and

16 Translation by Geoffrey D. Dunn, Tertullian (The Early Church Fathers; London: Routledge, 2004), 108.

17 For the view that Tertullian (as well as Justin Martyr, Tatian, Origen and A rnobius of Sicca) embraced the term $\beta \alpha \alpha \beta \alpha \rho \alpha_{\text {c }} /$ barbarus and adopted it for Christian purposes, see A ntonova, 'Spread of Christianity,' 69-85. Antonova also points out the different nuances of the term among these early Christian writers. For Tertullian's use of different terms for 'heathen' and these terms' different uses by him, see Ian L. S. B alfour, 'Tertullian's Description of the Heathen,' in Papers Presented to the Eighth International Conference on Patristic Studies, Oxford 1979 (ed. E. E. Livingstone; StPatr 17; Oxford: Pergamon, 1982), 785-789.

18 Eusebius of Caesarea, 'Commentarius in Isaiam,' in Eusebius Werke, Band 9: Der J esajakommentar (ed. J. Ziegler; GCS; B erlin: A kademie, 1975), 3-411.

19 M ichael J. Hollerich, E usebius of Caesarea's Commentary on Isaiah: Christian Exegesis in the Age of Constantine (Oxford Early Christian Studies; Oxford: Clarendon, 1999), 77.

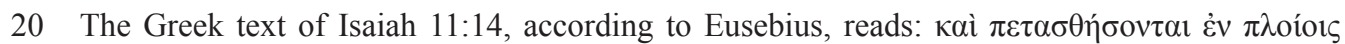

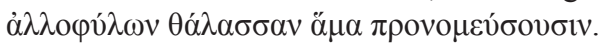

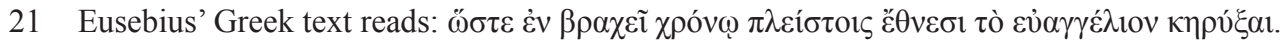




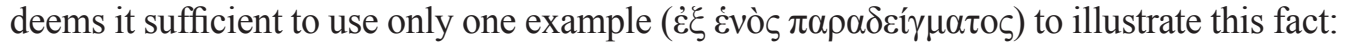
Paul, going to R ome by way of the sea, arrived on M alta and

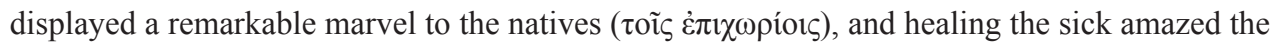

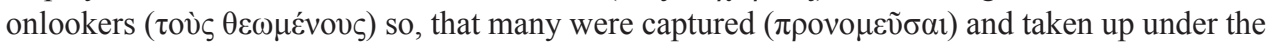

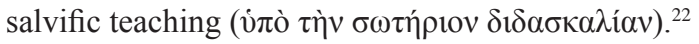

Eusebius next remarks that 'also those in the East' were 'captured' by the disciples as some of them went as far as Persia and India telling of what they know. The scope of Eusebius' argument is worldwide, as the proclamation occurs 'in the four corners of the earth'. For Eusebius, then, Acts 28:1-10 is one of the illustrative epitomes of universal evangelisation. He does not only think in terms of verbal proclamation: rather, Paul's deeds, especially his acts of healing, become the key element in his missionary activity. Although relying on a term such as $\dot{\alpha} \lambda \lambda \operatorname{ó}_{\varphi} \nu \nu \lambda_{0} \varsigma$ ('foreign') in his exegesis, ${ }^{23}$

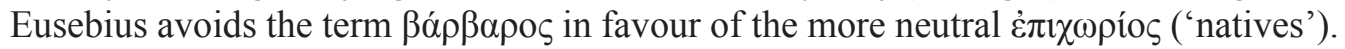
This softens the offensive impact of the word, but at the same time makes Eusebius' example apply to a wider range of missionary situations, allowing for the inclusion of those islands not populated by 'barbarians'. The change of terminology further creates the impression that Acts 28:1-6 and Acts 28:7-10 refer to the same group of people. Whether this was Eusebius' position is impossible to tell.

\subsection{John Chrysostom}

Not surprisingly, the prolific Chrysostom had much to say about Acts $28: 1-10 .{ }^{24} \mathrm{His}$ In Acta apostolorum homiliae ${ }^{25}$ is the oldest extant series of homilies on A cts that have come

22 Unless stated otherwise, English transl ations used in this article are the author's own.

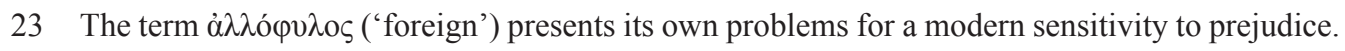

24 Chrysostom makes reference to the Acts 28:1-10 passage in three works not discussed here, as these references have no bearing on the scope of this article. They do not refer to any missionary activity, nor do they refer to M alta's inhabitants. The references can be found in J ohn Chrysostom, Stat. (PG 49:32); Laz. (PG 48:978); Hom. Rom. (PG 60:680). In these works, Paul is upheld as an example of faith. B asil of Caesarea has a similar argument with regard to Acts 28:1-10 in his H omiliae in Hexaemeron 9.6, worth noting here as emblematic of this type of use of Acts 28:1-10.

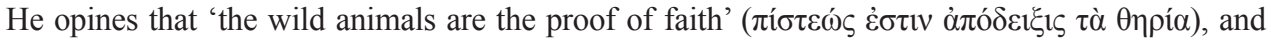
supports his argument by stating that Paul remained unharmed in the Acts 28:3-6 incident 'because

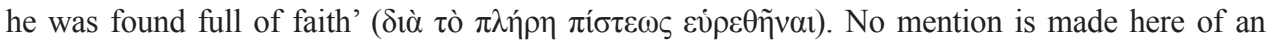
attempt at evangelisation; rather, the focus is on the quality of faith. He exhorts his listeners with

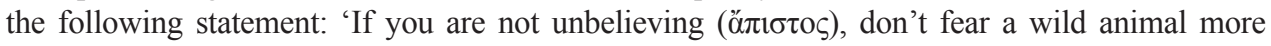

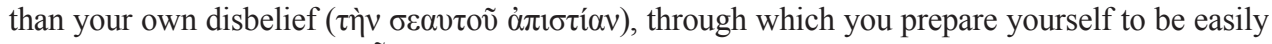

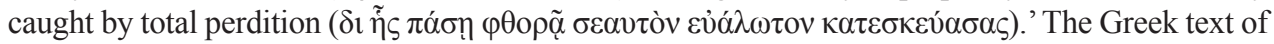
this passage can be found in Basil of Caesarea, 'Homiliae in Hexaemeron,' in Basile de Césarée. H omélies sur l'hexaéméron (ed. S. Giet; SC 26; Paris: Éditions du Cerf, 1968), 510-11.

J ohn Chrysostom, H om. Act.1-55 (PG 60:13-384). 
down to us, of which homily 54 has as its subject the $\mathrm{M}$ alta episode. ${ }^{26} \mathrm{Here}$, Chrysostom repeatedly uses 'barbarians' ( $\beta \alpha \alpha \rho \beta \alpha \rho o$ ) for the island's inhabitants. His stance towards them is positive - noting especially their 'kindness' $(\varphi \imath \lambda \alpha v \theta \rho \omega \pi i \alpha) .{ }^{27} \mathrm{He}$ regards the

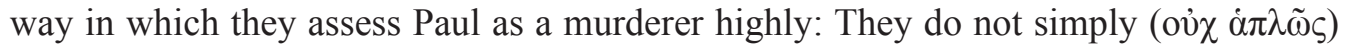
pronounce him a murderer, but spoke 'reverently' ( $\alpha i \delta \varepsilon \sigma i ́ \mu \omega \varsigma)$ to each other and based their judgement on the grounds that 'they understand that God is present everywhere, and that, even though someone may escape many things, he will not escape in the end' ${ }^{28}$ For this reason, the 'barbarians' 'were more philosophical than the philosophers'. ${ }^{29}$ Clearly, Chrysostom is of the opinion that there is such a thing as 'natural judgement' ( - the present author's emphasis). ${ }^{30} \mathrm{He}$ might not view the 'barbarians' in a negative light, but he does speak with a sense of cultural superiority. This can further be seen when he uses them as a rhetorical foil - against which both the J ews and Chrysostom's contemporaries come off second best by not acting as correct as their 'lessers', the 'barbarians', did. With regard to the J ews, he notes the following:

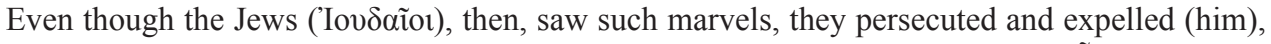
but without seeing anything, the barbarians ( $\beta \alpha \dot{\alpha} \beta \beta \alpha \rho \iota)$ were kind ( $\varphi \imath \lambda \alpha \dot{\alpha} \theta \rho \omega \pi \mathrm{ol} \tilde{\eta} \sigma \alpha v)$ - out of circumstance alone. ${ }^{31}$

26 John Chrysostom, Hom. Act.1-55 (PG 60:373-80).

27 For Chrysostom, the term $\varphi \imath \lambda \alpha \nu \theta \rho \omega \pi i \alpha$ has here the meaning of 'kindness' or 'generosity' and not 'love of humankind', as he explicitly links their $\varphi \imath \lambda \alpha v \theta \rho \omega \pi i \alpha$ with kindling a fire and receiving the shipwrecked people. To quote him: 'How the barbarians offer kindness, he explains:

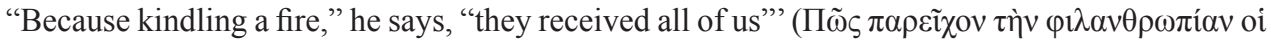

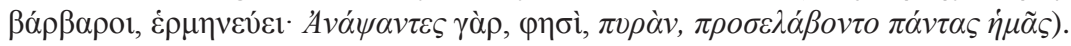

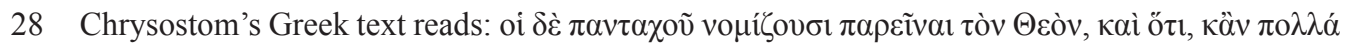

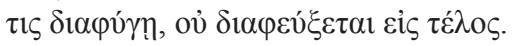

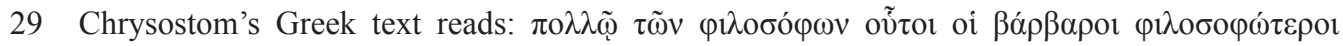

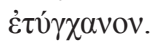

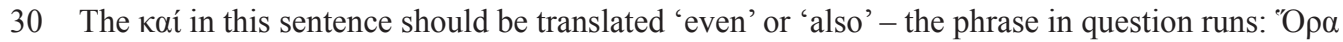

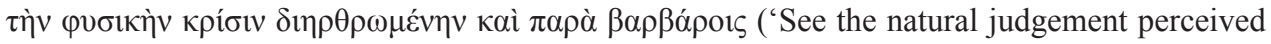
even among the barbarians'). This emphatic kai lessens the probability that Chrysostom might be playing here on the concept of 'barbarian philosophy', which the early Christian apologists adopted and appropriated for their own rhetorical needs, viewing 'themselves as the proud possessors of a barbaros philosophia, different, older than and superior to the Hellenic philosophical tradition.' (The quotation is from Stroumsa, Barbarian Philosophy, 57.) Cf. Windisch, TD NT 549.

31 John Chrysostom, Hom. Act. 1-55 (PG 60:375). 
For his fellow Christians, Chrysostom upholds the 'barbarians' as an example on serving the incarcerated:

A nd see how they do not assault them immediately, but respected them for a time because of

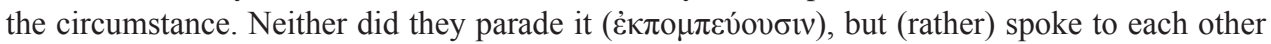
- because the chains taught them to be suspicious. Indeed, they were captives. Let those who say: 'Don't do good to those in prisons' be ashamed ( $\alpha i \sigma \chi v v \varepsilon \dot{\sigma} \theta \omega \sigma \alpha v)$ ! Let us be shamed by

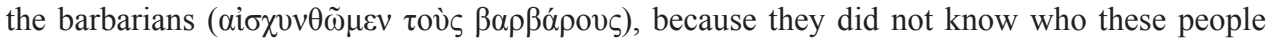

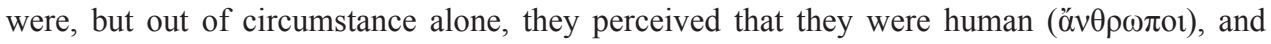
consequently regarded them worthy of kindness $(\varphi \imath \lambda \alpha v \theta \rho \omega \pi i \alpha \varsigma \dot{\eta} \xi i \omega \sigma \alpha \nu) .{ }^{32}$

Chrysostom does not complain about or condemn the 'barbarians' for thinking Paul a god, but describes their opinion as an 'exaggeration' ( $v \pi \varepsilon \rho \beta 0 \lambda \eta$ ). He notes the similarity with the incident at Lystra (cf. Acts 14:8-18), but does not explicitly note that there, Paul (and B arnabas) reacted strongly and immediately corrected the Lycaonians' view (A cts 14:14-17).

It is unclear whether Chrysostom regards the 'barbarians' and the people healed by Paul in A cts 28:9 as one and the same, but it is certain that he considered the whole episode to have a missionary character. A fter musing on the healings and the reception of Paul by Publius and the island's inhabitants, Chrysostom states:

See how all this is done for the sake of Paul, to the end that the prisoners should believe (

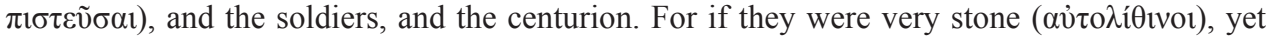
from the counsel they heard him giving, and from the prediction[s] they had heard him making, and from the miracles they knew him to have wrought, and from the sustenance they by his means enjoyed, they must have got a very high notion of him. $\left(\mathrm{NPNF}^{1}{ }^{11: 320)^{33}}\right.$

No explicit mention is made in this passage of the 'barbarians' or the people who have been healed coming to faith, but Chrysostom's scope is clearly bigger than simply this episode: the counsel and prediction(s) refer to previous incidents in the A cts narrative (cf. Acts 27:10,21-26,31,33-34). At the very least, those who have been healed are by his reckoning included among the converted - on account of preaching - as he explains in another passage:

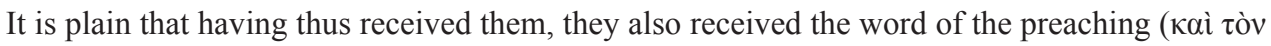

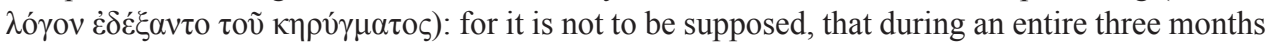
they would have had all this kindness shown them, ${ }^{34}$ had these persons not believed strongly, and

32 J ohn Chrysostom, Hom. Act. 1-55 (PG 60:375).

33 The Greek text can be found in Chrysostom, H om. Act. 1-55 (PG 60:374).

34 This translation is of the Greek text as emended by George B. Stevens in NPNF ${ }^{1}$ (11:321). His text critical decision is sound (see the discussion ad loc.), but it is worth noting that the

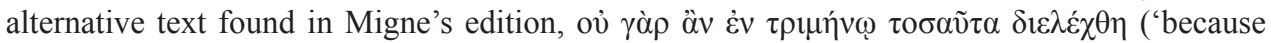
if in a three month period he conversed such things [with them]') would not belie the present argument. M igne's text can be found in J ohn Chrysostom, H om. Act.1-55 (PG 60:376). 
herein exhibited the fruits (of their conversion): so that from this we may see a strong proof of the great number there was of those that believed. (NPNF ${ }^{1} 11: 321$ ).

The missionary character of the Acts 28:1-10 passage according to Chrysostom's assessment is indirectly visible in his In epistulam ad Ephesios homiliae (8)..$^{35}$ In remarking on Ephesians 4:1, Chrysostom notes that it is especially when the devil (o $\delta 1 \alpha$ á $\left.\beta \lambda_{0}\right)$ ) strikes that he is hit hardest; for 'whenever he binds the servants of God, the Word more greatly spreads' ${ }^{36} \mathrm{He}$ proves his point with a list of examples from the life of Paul, including his imprisonment at J erusalem and R ome, and also his encounter with the snake on M alta. However, whereas the other examples include the effect of Paul's imprisonment (e.g., Felix's openness to hear more of the gospel in Acts 24:25-26), ${ }^{37}$ nothing is said about the outcome of the episode on $\mathrm{M}$ alta. That Chrysostom viewed the episode as missionary in character is a reasonable assumption, but must be inferred from the context of the passage.

Another passage from which Chrysostom's view of the 'barbarians' of Acts 28:1-6 can be inferred is found in an exposition of Psalm 7 in his Expositiones in Psalmos. ${ }^{38}$ Here he paints a more negative view of their assessment of Paul in A cts 28:4. A ccording to Chrysostom, 'many of the foolish' ( $\pi \mathrm{o} \lambda \lambda$ oì $\tau \tilde{\omega} v \dot{\alpha} v o \eta \dot{\tau} \omega v)$ think they can surmise from an individual's circumstances his or her 'manner of living' (ßíov). He lists as examples Job's friends and 'the barbarians' (oi $\beta$ áp $\beta \alpha \rho o t)$ of Acts 28:2-6, indirectly equating them with the 'foolish'.

35 John Chrysostom, Hom. Eph. 1-24 (PG 62:65). Another reference to the Malta episode can be found earlier in the same homily (p. 57). Chrysostom uses the incident related in Acts 28:3-5 in commenting on Ephesian 4:1 to prove the power of Paul's bonds: the snake did him no harm because it 'feared' (ฤ’ $\delta \varepsilon \sigma \theta \eta)$ his shackles. Chrysostom employs a similar argument - and the same word (ฤฺ́ $\delta \theta \eta)$ for the snake's fear, but this time of Paul's hands - in John Chrysostom, H om. 1 Cor. 1-44 (PG 61:112). These two latter passages have no bearing on the present investigation.

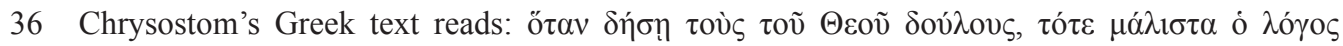
$\dot{\varepsilon} \pi 1 \delta \dot{\delta} \delta \omega \sigma \mathrm{t}$.

37 Chrysostom does not mention the reason for Felix's continued conversations with Paul as found in the Acts narrative, namely, that Felix 'hoped that he would be given money by Paul' ('் $\lambda \pi i^{\prime} \zeta \omega v$

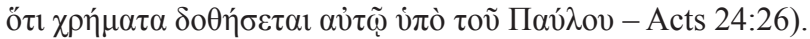

38 John Chrysostom, Exp. Ps. (PG 55:92). Chrysostom makes mention of Acts 28:3-6 once more in his exposition of Psalm 148 (p490), where he exhorts his listeners to remember the transgression in paradise whenever they see a wild animal such as a lion or snake. These animals were previously tame; but after the transgression they have become wild. Daniel in the lion's den and Paul's encounter with the snake are listed as examples of how to react when these animals are seen: with faith. A similar argument can be found in an exposition of Psalm 8:7-9 in Didymus the Blind, 'Fragmenta in Psalmos,' in Psalmenkommentare aus der Katenenüberlieferung (ed. E. M ühlenberg; PTS 15; B erlin: De Gruyter, 1975), 148. Didymus does not explicitly take faith as the key, but opines that 'the righteous' (oi díkalol) can perform these feats. 


\subsection{Ambrose of Milan}

A number of glimpses into an ancient Christian theologian's understanding of the Acts 28:1-10 episode is provided by Ambrose of Milan. In Expositio euangelii secundum L ucam (8.16), ${ }^{39}$ he concerns himself with the parable of $L$ azarus and the rich man (Luke 16:19-31). In commenting on Lazarus' sores, the discussion turns towards Paul:

Oh happy wounds, which keep out perpetual pain, oh rich morsels (uberes micae), ${ }^{40}$ you who drive away the everlasting thirst (ieiunium sempiternum), you who fill up the begging have-not with eternal nourishment! The chief ruler of the synagogue (archisynagogus) threw you from his table, when he denied the inner mysteries of the prophetic scriptures and the law; for the morsels are the words (sermones) of the scriptures, of which it is said: 'A nd you have cast my words (sermones) behind you.' ${ }^{41}$ The scribe threw you out, but Paul most carefully brought you together in his injuries (in iniuriis suis), gathering the common people (plebem). ${ }^{42}$ They licked his wounds, they who (qui) saw him unshaken by the bite of a serpent, and with the serpent shaken off, believed (crediderunt). That guardian of the prison licked (his wounds), who washed the wounds of Paul and believed. Blessed hounds, into which drips the fluid of such wounds, so that it fills their heart and paints their throats ...

The passage has a clear evangelistic theme, bizarre as it may seem to a modern audience. The Lukan parable has been overlaid with two stories of conversion, right up to the dogs licking Lazarus' sores (Luke 16:21), who are interpreted as the converted. The 'barbarians', identified by Ambrose simply as 'they who....saw' (qui... viderunt), come to faith after seeing the incident with the snake. A mbrose does not have anything to say about them thinking Paul a god, which is the only outcome of the incident in the Acts narrative (cf. Acts 28:6). Both the avoidance of the term barbarus and the neglect of commenting on Paul being perceived as a god could be due to the poetic nature of the passage.

Earlier in the same work (7.58), ${ }^{43} \mathrm{~A}$ mbrose does mention that the 'barbarians' called Paul a god, ' which poison was not able to harm' . In this passage, how ever, the 'barbarians' are described as incolae. The term has a range of meanings from 'inhabitant/resident',

39 A mbrose of Milan, 'Expositio euangelii secundum Lucam,' in Sancti Ambrosii Mediolanensis opera (ed. M. A driaen; CCSL 14; Turnholt: B repols, 1957), 303-04.

40 With uberes micae... ieiunium sempiternum ('rich morsels ... everlasting thirst'), A mbrose sets up a pun: the adjective uber ('rich') is likened to the noun uber ('breast').

41 Cf. LXX Ps. 49:17.

42 The term plebs could al so take the meaning of 'nation' in late L atin, in which use it is synonymous with populus. See Charlton T. L ewis and Charles Short, A Latin Dictionary (Oxford: Clarendon, 1879), 1386.

43 A mbrose of M ilan, 'Expositio euangelii secundum Lucam,' 233. 
'foreign resident' or 'native' - the latter of which most closely approximates A mbrose's use here. ${ }^{44} \mathrm{~A}$ nother term is opted for by A mbrose in his Exameron $(6.28),{ }^{45}$ where the 'barbarians' are referred to as intuentes ('onlookers'). The context of the passage, as with many of the other early Christian writers, concerns humankind's relation with animals. Snakes and other venomous animals might be 'stumbling blocks and objects of fear' to some, A mbrose states, but to others, they stand in the same relationship as paedagogi ${ }^{46}$ to young children (parvolis). As the whip of a paedagogus trains a young child to live a sober life, so the serpent trains the 'weak stage of the mind' (infirma animi aetas). A grown man can not be harmed by the paedagogus' whip and does not fear it - and so it is with faith. Ambrose quotes Psalm 90:13 in the Septuagint to prove his point, ${ }^{47}$ as well as Paul's encounter with the snake in Acts 28:3-6. Paul is 'invulnerable', and 'found great veneration (venerationis) among the onlookers (intuentes)'.$^{48} \mathrm{~A}$ part from calling the 'barbarians' the neutral term intuentes, A mbrose al so appears to mollify their calling Paul a god; at least, the term veneratio is ambiguous and the term deus is not used directly. In yet another instance, in De interpellatione lob et Dauid (4.1.5), ${ }^{49} \mathrm{~A}$ mbrose downplays the difficult saying of the 'barbarians'. He first appeals to Mark 16:17-18 to prove what deeds the faithful are capable of, ${ }^{50}$ after which he puts forth Paul and the snake (Acts 28:3-6) as an example. He ends his paraphrase of the incident with:

Therefore, those who saw (videntes) him did not think that he was born in the condition of a human (hominis condicione genitum), but as if (tamquam) through the grace of a god (dei gratia) he was raised higher than humans (editum supra homines esse).

The explicit ascription of divinity by the 'barbarians' in Acts 28:6 to Paul has been tempered by the introduction of another actor as bestower of this divine quality: a god or

44 See Lewis and Short, Latin Dictionary, 924-925.

45 A mbrose of M ilan, 'Exameron,' in Sancti Ambrosii opera: Pars prima (ed. K. Schenkl; CSEL 32; Prague: Tempsky, 1896), 229. Another reference to Acts 28:3-6 can be found earlier in this work, where A mbrose upholds Paul as an example of a faithful man whose 'merits of devotion saved (him)' (devotionis merita seruarunt). See A mbrose of M ilan, 'Exameron,' 119-20.

46 The term paedagogus is kept untranslated due to its technical nature. The paedagogi were slaves who were tasked with the education of younger children.

47 The quote of LXX Ps. 90:13 as found in Ambrose reads: super aspidem et basiliscum ambulabis et conculcabis leonem et draconem ('over the viper and the basilisk will you walk, and you will trample on the lion and the serpent').

48 A mbrose's $L$ atin text reads: plus apud intuentes venerationis invenit.

49 A mbrose of M ilan, 'De interpellatione lob et Dauid,' in Sancti Ambrosii opera: Pars altera (ed. K. Schenkl; CSEL 32; Prague: Tempsky, 1897), 270.

50 The relevant part in Mark 16:18 reads, in Ambrose's text: serpentes tollent et si mortiferum quid biberint, non illis nocebit ('they will lift serpents and if they drink something poisonous, it will not harm them'). 
God. A mbrose's use of videntes ('those who saw') to describe the 'barbarians' follows on his description of them as barbari earlier on. This is the only place in A mbrose's references to the Acts episode where the term is used. A mbrose, then, did consider Paul's actions among the 'barbarians' (i.e. Acts 28:1-6) as missionary.

The last part of Paul's stay on M alta is viewed by A mbrose in a similar light. In De patriarchis (12.57), ${ }^{51}$ he comments on the description of B enjamin in Genesis 49:27 ('Benjamin is a ravenous wolf (lupus); he continually eats in the morning and towards evening distributes the meal to the leaders (principibus)' $).{ }^{52} \mathrm{As}$ Paul is from the tribe of Benjamin (cf. Phil. 3:5; Rom. 11:1), A mbrose states that Paul was a 'wolf' (lupus) in persecuting the church, but became a shepherd (pastor) who distributed food 'to the leaders' (principibus). A mong these are to be reckoned Sergius Paulus (cf. Acts 13:7) and $M$ alta's princeps, Publius, who 'received the grace of the L ord' when 'he (i.e. Paul) preached' (eo disputante) to them.

\section{CONCLUSION}

This article has examined the reception of Acts 28:1-10 in the writings of the early Greek- and Latin speaking church of the first five centuries C.E. to determine whether the early church perceived this episode as missionary in character. This indeed proves to be the case..$^{53}$ The missionary character of Paul's actions is substantiated in a variety of ways. His resistance to the snake's bite (e.g. Eusebius; A mbrose; cf. Tertullian); his healing actions among the island's inhabitants (e.g. Eusebius; Chrysostom; cf. Tertullian); his honourable reception by the people of Malta (e.g. Chrysostom); or

51 A mbrose of Milan, 'De patriarchis,' 158-59.

52 A mbrose's Latin text reads: - B eniamin lupus rapax, mane edet adhuc et ad vesperum dividet escam principibus.

53 Cyril of Jerusalem also refers to the Acts 28:1-10 episode, but his view on it is difficult to discern. $\mathrm{H}$ is only reference to the pericope is in chapter 17 of his $\mathrm{C}$ atecheses ad illuminandos, where Cyril relates the A cts narrative in summary form. A fter noting that the Holy Spirit provided Paul with the means to stay unharmed by the serpent and to accomplish manifold healings on those who were sick, Cyril immediately recounts that 'this Holy Spirit also led him, the former pursuer, to royal Rome as proclaimer (ки́рvка) of Christ'. The juxtaposition of these two episodes, and especially the fact that Paul is described as 'proclaimer of Christ', might indicate that Cyril saw Paul's acts of healing and his resistance to the serpent's bite as missionary activity. However,

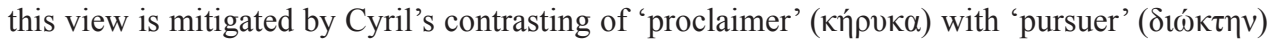
in such close vicinity to him mentioning that the conversion of many of the Jews happened 'on that spot' ( $\alpha$ vó $\theta \mathrm{r}$ - i.e., Rome). Cyril's aim in calling Paul a 'proclaimer of Christ' in this passage is focused on sketching Paul's move from pursuer to proclaimer with regard to the J ews. Consequently, this passage does not contribute to our understanding of Cyril's views on Paul's actions among the 'barbarians'. The Greek text of this passage can be found in Cyril of J erusalem, 'Catecheses ad illuminandos 1-18,' in Cyrilli Hierosolymorum archiepiscopi opera quae supersunt omnia (ed. W. C. Reischl and J. Rupp; Munich: Lentner, 1860), 290. 
straightforward preaching assumed by some (cf. Chrysostom; A mbrose) could have won people for the Christian faith.

The term 'barbarian' in Acts $28: 2,4$ is received and used by some in a neutral fashion, ${ }^{54}$ but seemingly shunned by others (e.g. Eusebius; A mbrose). Only Chrysostom uses the term in a slightly haughty manner; however, he has a high opinion of the 'barbarians' themselves, even if only for rhetorical purposes. For the most part, the early Christian writers did not have much to say about the view of the 'barbarians' that Paul was a god. The only writers who directly refer to this incident, Chrysostom and Ambrose, soften the statement. Whether the 'barbarians' in Acts 28:1-6 and the island's inhabitants in Acts 28:7-10 are the same group can not be discerned from the extant writings of the early church (but cf. Eusebius). However, this question might be moot: the early church's missionary reading of A cts 28:1-10 would have brought both groups under its missionary scope.

\section{BIBLIOGRAPHY}

Antonova, Stamenka E. 'Barbarians and the Empire-Wide Spread of Christianity.' Pages 69-85 in The Spread of Christianity in the First F our Centuries: Essays in Explanation. Edited by William V. Harris. Columbia Studies in the Classical Tradition 27. Edited by W. V. Harris. Leiden: B rill, 2005.

Balfour, Ian L. S. 'Tertullian's Description of the Heathen.' Pages 785-89 in Papers P resented to the Eighth International C onference on Patristic Studies, Oxford 1979. Edited by E. E. Livingstone. Studia Patristica 17. Oxford: Pergamon, 1982.

Börstinghaus, Jens. Sturmfahrt und Schiffbruch: Zur lukanischen Verwendung eines literarischen Topos in Apostelgeschichte 27,1-28,6. Edited by J. Frey. Wissenschaftliche Untersuchungen zum Neuen Testament 2/274. Tübingen: Mohr, 2010.

Dihle, A lbrecht. Die G riechen und die F remden. M ünchen: B eck, 1994.

Dunn, Geoffrey D. Tertullian. E dited by C. Harrison. The Early Church Fathers. L ondon: Routledge, 2004.

54 Two writers not treated in this article, Origen and A mbrosiaster, also use the term in a neutral way, as they are simply citing the biblical text. Origen's reference can be found in Origen, Selecta in Genesim (fragmenta e catenis) (PG 12:96-97). He uses Acts 28:4-6 to substantiate his argument that man has authority over snakes. A mbrosiaster makes use of Acts $28: 2$ in his commentary on the last phrase of 2 Cor. 11:27 ('in cold and nakedness' - in frigore et nuditate). He does little more than quote the biblical text of Acts 28:2, in a slightly different order, to prove that Paul was occasionally cold and naked. A lthough the context in which A mbrosiaster's discussion on 2 Cor. 11:27 takes place does partially concern Paul's missionary activities, there is no explicit link made by him between evangelisation and Acts $28: 2$. The Latin text of A mbrosiaster's passage can be found in A mbrosiaster, 'Commentarius in epistulas Paulinas B,' in Ambrosiastri qui dicitur commentarius in epistulas Paulinas (ed. H. J. Vogels; CSEL 81; Vienna: Hoelder, 1968), 296. 
Funck, Bernd. 'Studie zu der Bezeichnung ßápßapos.' in Untersuchungen ausgewählter altgriechischer sozialer Typenbegriffe und ihr F ortleben in Antike und Mittelalter. Edited by $E$. C. Welskopf. Sozial eTypenbegriffe im alten Griechenland und ihr Fortleben in den Sprachen der Welt 4. B erlin: A kademie, 1981.

Gaventa, Beverly R. The Acts of the Apostles. A bingdon New Testament Commentaries. Nashville: A bingdon, 2003.

Gruen, Erich S. Rethinking the Other in Antiquity. Princeton: Princeton U niversity Press, 2011.

Hall, Edith. Inventing the Barbarian: Greek Self-Definition through Tragedy. Oxford Classical M onographs. Oxford: Clarendon, 1989.

Hollerich, M ichael J. E usebius of Caesarea's C ommentary on Isaiah: Christian Exegesis in the Age of Constantine. Oxford Early Christian Studies. Oxford: Clarendon, 1999.

J ervell, Jacob. Die A postelgeschichte. K ritisch-exegetischer K ommentar über das N eue Testament 3. Göttingen: Vandenhoeck \& Ruprecht, 1998.

J ohnson, L uke T. The Acts of the Apostles. Sacra Pagina Series 5. Collegeville: The Liturgical Press, 1992.

K ittel, Gerhard and Gerhard Friedrich. Theological Dictionary of the New Testament. Translated by G. W. Bromiley. Grand Rapids: Eerdmans, 1964.

K rodel, Gerhard A. Acts. A ugsburg Commentary on the New Testament. M inneapolis: Augsburg, 1986.

Lewis, Charlton T. and Charles Short. A Latin Dictionary. Oxford: Clarendon, 1879.

$\mathrm{M}$ arshall, I. Howard. The Acts of the Apostles: An Introduction and Commentary. Tyndale New Testament Commentaries. L eicester: InterVarsity, 1980.

Parsons, M ikael C. Acts. Paideia. Grand Rapids: Baker A cademic, 2008.

Patrologia graeca. Edited by J.-P. Migne. 162 vols. Paris, 1857-1886.

Patrologia latina. Edited by J.-P. Migne. 217 vols. Paris, 1844-1864.

Pelikan, J aroslav. Acts. SCM Theological Commentary on the Bible. London: SCM, 2006.

Pervo, Richard I. Acts: A Commentary. Hermeneia. M inneapolis: Fortress, 2008.

Peterson, David. The Acts of the Apostles. The Pillar New Testament Commentary. Grand Rapids: Eerdmans, 2009.

Roloff, J ürgen. Die Apostelgeschichte. Das Neue Testament Deutsch 5. Göttingen: Vandenhoeck \& Ruprecht, 1981.

Schnabel, Eckhard J. J esus and the Twelve. Vol. 1 of Early Christian M ission. Downers Grove: InterVarsity, 2004.

- - - Paul and the Early Church. Vol. 2 of Early Christian M ission. Downers Grove: InterVarsity, 2004.

- - - . Paul the M issionary: Realities, Strategies and M ethods. D owners G rove: InterVarsity, 2008.

Schneider, Gerhard. Die Apostelgeschichte: II. Teil: Kommentar zu Kap. 9,1-28,31. Herders Theologischer Kommentar zum N euen Testament 5. Freiburg: Herder, 1982.

Stenschke, Christoph W. L uke's P ortrait of G entiles P rior to Their Coming to F aith. W issenschaftliche Untersuchungen zum Neuen Testament 108. Tübingen: M ohr, 2008. 
Stroumsa, Guy G. Barbarian Philosophy: The Religious Revolution of Early Christianity. Edited by M. Hengel and O. Hofius. Wissenschaftliche Untersuchungen zum Neuen Testament 112. Tübingen: M ohr, 1999.

Talbert, Charles H. Reading Acts: A Literary and Theological Commentary on the Acts of the Apostles. Rev. ed. M acon: Smyth \& Helwys, 2005.

Tannehill, R obert C. 'R ejection by J ews and Turning to the Gentiles: The Pattern of Paul's M ission in A cts.' Pages 130-41 in Society of Biblical Literature 1986 Seminar Papers. Edited by Kent H. Richards. Society of Biblical Literature Seminar Papers Series. Atlanta: Scholars Press, 1986.

The Nicene and Post-Nicene Fathers, Series 1. Edited by P. Schaff. 1886-1889. 14 vols. Repr. Peabody: Hendrickson, 1994.

Van Eck, John. Handelingen: De Wereld in het Geding Commentaar op het Nieuwe Testament. K ampen: Kok, 2003.

Witherington, Ben. The Acts of the Apostles: A Socio-Rhetorical Commentary. Grand Rapids: Eerdmans, 1998. 